\title{
Challenging identity \\ hierarchies: Gender and \\ consociational power-sharing
}

The British Journal of Politics and International Relations 2016, Vol. 18(3) 618-633

(C) The Author(s) 2016

Reprints and permissions: sagepub.co.uk/journalsPermissions.nav

DOI: $10.1177 /|369| 48 \mid 16647334$ bpi.sagepub.com

@SAGE

\author{
Ronan Kennedy', Claire Pierson² \\ and Jennifer Thomson ${ }^{3}$
}

\begin{abstract}
Consociational democracy has become the most influential paradigm in the field of powersharing institutional design and post-conflict peacebuilding. Consociation institutes representation for certain formerly excluded groups. However, it simultaneously inhibits effective political representation for groups that do not align with the societal divisions that consociation seeks to accommodate, specifically the 'additional' cleavage of gender. Given the extensive use of the consociational model as a peacebuilding tool in divided states and the growing awareness of the disproportionate negative effect of conflict on women, there is a surprising lack of consideration of the effect that consociational power-sharing has on women's representation. This article considers the specific impact that the consociational model has on women's representation. We argue that because gender is an integral factor in conflict, it should therefore be integral to postconflict governance. With empirical reference to contemporary Northern Ireland, it is illustrated that consociationalism is a 'gender-blind' theory.
\end{abstract}

\section{Keywords}

consocationalism, gender, Northern Ireland, post-conflict, power-sharing

$\ldots$ the problem was the way we posed the problem.

(What Is a Woman? Toril Moi, 2001: 119)

\section{Introduction}

As practically deployed in peace agreements in Northern Ireland, Lebanon, Macedonia and Bosnia-Herzegovina, among others, consociational power-sharing is increasingly

\footnotetext{
'University College Dublin, Ireland

2Manchester Metropolitan University, UK

${ }^{3}$ Queen Mary University of London, UK
}

\section{Corresponding author:}

Jennifer Thomson, School of Politics and International Relations, Queen Mary University of London, Mile End Road, London EI 4NS, UK.

Email: j.c.thomson@qmul.ac.uk; jennifercthomson@gmail.com 
relied upon in the development of post-conflict governmental structures. Yet, despite this positive global reception, consociational government is not without its faults. While encouraging representation along ethnic or religious lines, it simultaneously inhibits effective political representation for those whose primary political identities do not align with the societal divisions it seeks to ameliorate. With ethno-national identity dominating this framework for conflict resolution, there is little space for any other understanding of identity or difference. Equality of representation and the ensuing legitimacy of political institutions are framed within the ethno-national paradigm. This article explores how identities 'other' than ethno-nationalism fit into consociational government, specifically addressing how power-sharing impacts women's political representation.

The consociational model has extensive use as a peacebuilding tool in divided states (Taylor, 2009; Wilson, 2010). Simultaneously, there is a growing awareness of the disproportionate negative effect of conflict on women (Meintjes et al., 2001; Ní Aoláin, 2006). The dearth of literature that examines the effect that consociational power-sharing has on women's representation is thus surprising. The work that has been produced has developed largely from comparative, 'real-life' examples (Byrne and McCulloch, 2012; Rebouche and Fearon, 2005) and from within considerations of the global Women, Peace and Security agenda, most clearly typified in United Nations Security Council Resolution 1325 (UNSCR 1325) (Byrne and McCulloch, 2012). As such, it has engaged less with consociational theory per se. Although we anchor our argument here in the empirical case of contemporary Northern Ireland, we are more concerned to address the conceptual misalignment between gendered understandings of conflict and the consociational model as a means to create a stable peace. Like Byrne and McCulloch, we argue that 'the problem begins at the level of theory' (Byrne and McCulloch, 2012: 566) and that the lack of consideration given to gender by consociational theorists must be addressed in order to consider the inadequacies of the theory itself.

This article thus facilitates an understanding of the specific impact that the consociational model has on women's political representation (both descriptive and substantive). It argues that consociationalism is a 'gender-blind' theory and thus an incomplete/inadequate solution to the 'problem' of conflict. We work from a basic argument, outlined in the section 'Gendering ethno-national conflict', that all conflict is gendered and that consociational prescriptions for post-conflict governance ignore this actuality. It is further argued that consociation's emphasis on formal political structures, and women's dominance in community or grassroots, as opposed to party politics, hinders their representation. An overview of consociational theory, its development and its inattention to issues of gender is then provided. We anchor our argument in contemporary Northern Ireland, as a means of illustrating the ways in which post-conflict consociational governance in the province has hindered movement around women's descriptive and substantive representation.

\section{Gendering ethno-national conflict}

The lack of consideration given to gender in consociational theory is notable given the stress that contemporary feminist scholarship has placed on the gendered nature of conflict, including ethno-national-based conflicts. Within feminist narratives of conflict, the role of gender and patriarchy has been understood to be a primary cause of war (see for example Reardon, 1996: 10). Considering conflict, Cynthia Enloe asks, 'What if 
patriarchy is the big picture?' (Enloe, 2005). Enloe reasons that the fundamental cause of conflict and the key to its resolution lie in the specific societal constructions of public and private masculinised privilege and that in order to expose and understand this privilege, it is necessary to examine the lives of women. This argument contrasts starkly with the common position of ethno-national movements, which view gender equality as subordinate to the national project (Enloe, 1989: 62), and peacebuilding initiatives, which position gender equality as an 'add-on' to mainstream activities (Anderlini, 2007: 205).

Indeed, particular explanatory narratives of divided societies, which do not consider women, grow dominant over time and as such become naturalised or self-evident. Interrogating these narratives from an alternative perspective can reveal marginalised accounts and understandings of the origins of conflict. Such understandings have implications for current mainstream initiatives for peacebuilding and reconciliation. The normative framings of ethno-national conflict have been questioned at the academic level (Wilson et al., 2007; Zalewski and Barry, 2008), yet are continually reproduced through mechanisms put in place to resolve or end violence and inequality perpetuated by ethnonational antagonisms (Zalewski and Barry, 2008: 2). Alternative understandings of societies in conflict thus explore how different groups of people are affected and thus widen the possibilities of what may be considered conflict-related concerns. As Bell and O'Rourke note,

While feminists acknowledge that 'the' conflict is significant, and may indeed be at the vanguard of movements to end the conflict, they also tend to ask questions about the nature of political conflicts: whether there is one conflict or many and how levels of public and private conflict intertwine in women's lives. (Bell and O'Rourke, 2007: 38)

Levels of gender equality have proven to be integrally linked to a state's propensity to engage in intrastate violence. Two studies providing statistical analysis of the percentage of women in parliament and the ratio of female-to-male higher educational attainment (Melander, 2005), fertility rates and percentage of women in the labour force (Caprioli, 2005) have revealed that states characterised by gender discrimination and structural hierarchy are permeated with norms of violence that make internal conflict more likely (Caprioli, 2005: 172). Conservative notions of gender and gender hierarchies, which embody a belief in male domination, are created and sustained through cultural norms, socialisation, gender stereotyping and the threat of violence. Such gender orders foster militarism and as such make violence appear a possible and even natural outcome of societal divisions (Galtung, 1990).

Equally, however, it is also recognised that conflicts can have a potentially liberating effect for women, with the opening of 'intended and unintended spaces for empowering women, effecting structural and social transformations and producing new social, economic and political realities that redefine gender and caste hierarchies' Machanda (2001: 99). Such situations offer the potential to disrupt and challenge gender orders and make women's particular inequalities more visible. Yet, women's contributions are regularly marginalised in the aftermath of conflict (Meintjes et al., 2001). This marginalisation is accompanied by the reconstitution of male power in the public sphere and the 'natural' positioning of men in roles of leadership whether at the political or community level.

In societies moving out of conflict, women engage and are active in movements for justice, the enforcement of human rights norms, institutional reform and the provision of security, yet 'they generally rely on structures that do not encourage them to think 
about the manifold ways in which they have been victimized' (Rubio-Marín, 2006: 22). Such societies notably lack gender-sensitive mechanisms for interpreting and addressing the structural harms and inequalities which particularly affect women. Ní Aoláin argues, 'the matters that are framed as central issues for resolution in transitional negotiations may only peripherally impact many women's day-to-day lives' (Ní Aoláin, 2006: 831). Accordingly, it remains necessary to re-evaluate transitions from a feminist perspective. By prioritising certain inequalities and ignoring others, the power relations exacerbated by conflict are reinforced and reflected in the conflict transformational society (Ward, 2004).

The causal link between gender inequality and conflict is thus often left unexplored. In the Northern Ireland context, work by academics and a number of activists on women's roles means that academic texts now include an 'obligatory chapter on women/feminism' (Ashe, 2008: 157). This approach is problematic in that it separates women and gender as issues, presenting them as isolated from or unimportant to analysis of conflict, or the development of peace and security. The perception of gender neutrality or gender irrelevance to the Northern Ireland conflict is broad reaching and has been well documented in feminist accounts of the Troubles (Ashe, 2007; Connolly, 1999; O'Rourke, 2013). Marysia Zalewski (2005) uses the example of a key explanatory text of the Northern Ireland conflict, Explaining Northern Ireland: Broken Images (McGarry and O'Leary, 1995), to express how gender is pervasive in our understanding even where it may not appear to be immediately present. Although the text presents itself as providing a more fragmented explanation, it in fact acts as a 'comfort text' reproducing a familiar and typical narrative which largely ignores the role of gender and feminism. Zalewski uses the text to explore how gender works in academic analysis through its exclusion or seeming unimportance; when women are made visible, it is often as an afterthought. This tendency works to maintain a hierarchy where women are secondary or 'other' (McGarry and O’Leary, 1995: 207).

A key example provided by Zalewski is the lack of importance that McGarry and O'Leary attach to patriarchy as a cause of the conflict. They explain that patriarchy cannot be an explanatory cause of conflict in Northern Ireland as it is present in all societies (McGarry and O'Leary, 1995: 212). This dismissal displays a lack of interrogation as to how patriarchy might display itself differently or more explicitly in certain societies and how this particular manifestation may contribute to increased militarisation or violence within a particular society. In fact, the dismissal of patriarchy is highly problematic as understandings of gender orders and in particular militarised masculinities are integral to the demilitarisation of a society coming out of conflict. As Ní Aoláin observes, narrow interpretations of processes of conflict resolution only resolve visible aspects of conflict:

... the underlying social and psychological dimensions of a conflicted society that have supported the resort to violence, and the elevation of particular forms of masculinity that accompany it, are not in any sense undermined or addressed by a formal disarmament process. (Ní Aoláin, 2006: 846)

Ethno-national identities have been presented as the fundamental cause of conflict in Northern Ireland (McGarry and O'Leary, 1995). The construction of ethno-national identity has been explored by multiple theorists and shown to be a highly gendered process (Yuval-Davis, 1993). The development of the nation, whether it is viewed as a historical 
invention or an imagined community (Day and Thompson, 2004; Gellner, 2008), is highly dependent on shared experience and history derived from a collective past of masculinised memory and hope (McClintock, 1993). This shared history is highly dependent on specific roles being assigned to men and women and highly institutionalised gender differences transmitting power and property to males. Women are seen to 'bear the brunt' of this form of identity politics in terms of their range of life choices (Imam and YuvalDavis, 2004). In conflict, the targeting of women, in particular for sexual violence, is viewed as an attempt to destroy a nation's culture and purity (McKay, 1998).

In the context of Northern Ireland, conservative and nationalist ideals of the role of motherhood appeal to both traditions within Irish Nationalism and British Unionism. Conservative Catholicism and evangelical Protestantism both revere and aim to uphold traditional gender roles. Within the perspective of Irish Nationalism, the concept of national territory as 'Mother Ireland' and the central figure of the Virgin Mary within Catholicism both posit ideals of womanhood as suffering self-sacrificing mothers (Sales, 1997). While there is less evocative imagery of women within the Protestant, unionist tradition, the Protestant church(es) draws sharp distinctions between male and female roles, implying strict moral codes surrounding women's sexuality and self-sacrificing nature for family and community. A common assumption is that women play a supporting rather than active role within unionism (Ward, 2006).

In conflict, the emasculation of the nation and protection of its women and children is often evoked as a reason to engage in militarised action. For example, concern over the feminisation of the Irish nation through British colonialism conflates with the rise in violence as a return to manhood for Irish men (Ashe, 2012). For Unionist and Loyalist men, the role of defenders of the community could be exercised through either joining the Royal Ulster Constabulary or a paramilitary organisation (Bairner, 1999). The Troubles reinforced men's power in the public and private sphere and held in place militarised forms of masculinity (Ashe and Harland, 2014).

Gender is thus fundamental to an understanding of ethno-national conflict and of the Northern Irish conflict in particular. Constructing post-peace settlement governance in a way that does not fully acknowledge the gender order ignores a key component of the problem. The following section considers consociational theory and how its gender blindness results in a re-inscription of the patriarchal norms of conflict described by feminist academia.

\section{Consociational theory}

The concept of 'consociational democracy' is most closely associated with the work of Dutch political scientist Arend Lijphart. In his ground-breaking work Democracy in Plural Societies (Lijphart, 1977), he identified what would later become known as the 'pillars' of consociational power-sharing:

- Grand coalition government, in which major segments are represented. Governance is on the basis of institutionalised power-sharing between the political representatives of ethnic blocs. This formula goes beyond simple majoritarianism as decisions must be reached on a cross-community basis (i.e. a majority in all major communities represented).

- Segmental autonomy for groups, whereby the individual segments (ethno-national, religious, linguistic etc.) retain control of cultural policy with regard to education and so forth. 
- Proportionality in the public sector that goes beyond executive and legislative representation mentioned above. It extends to areas such as policing, the civil service and the proportional allocation of public funds.

- Minority veto, to remove the threat of domination for either group. This provision can be engineered through special parliamentary majority or office holder (Lijphart, 1977). In the case of Northern Ireland, this veto takes the form of the often-abused 'Petition of Concern' (Thomson, 2015), whereby legislation can be blocked if it poses a 'threat' to one of the represented communities.

More recent writings on the consociational model, as best exemplified by McGarry and O'Leary (2004), demonstrate a clear shift from what is termed 'corporate' towards 'liberal' consociational power-sharing. Consociation in its original form had been described as having 'corporatist' elements, in that the conflictual groups are identified as a prerequisite and institutions are designed around this assumed reality. The corporatist framework was based on a view of identity that negated the possibility of groups changing over time or intragroup diversity. This early form of institutional design contained the four 'pillars' outlined above and was generally decried for its rigidity: it embodied an approach to identity that was fixed and monolithic. Despite these criticisms, elements of corporate consociationalism are still evident in contemporary conflict settlements. Bosnia and Herzegovina under the original Dayton accords, Northern Ireland under the 1998 agreement and Lebanon under the 1989 Ta'if Accords, for example, all display features of pre-determined arrangements based on ascriptive identities without necessarily being corporatist in the pre-determined need to categorise elected representatives on the basis of ethnic identity.

The main practical difference between corporate and liberal consociation is that corporate consociation

rests on the assumption that group identities are fixed, and that groups are both internally homogeneous and eternally bounded while liberal consociation rewards whatever salient political identities emerge in democratic elections, whether these are based on ethnic groups, on sub-group or trans-group identities. (McGarry, 2007: 172)

This latter formula, in theory, allows citizens to 'go beyond' the narrow confines of ascriptive identity and promote intragroup fractions and cross-group alliances.

Lijphart describes the genesis of the distinction between the corporate form of consociation and the more contemporary liberal form. The basis of this distinction lies in the idea of self-determination versus pre-determination of societal cleavages. Selfdetermination allows groups autonomy as opposed to sovereignty. Pre-determination suggests that the groups who will potentially share power are identified in advance.

In liberal consociational states, the basis for self-determination is the electoral system, where voters animate the proportionality pillar through the selection of candidates in PR (proportional representation) lists. While citizens are free to vote for whoever they wish, the assumption is that voters will choose to elect candidates for parties that best serve the interest of their electorally mobilised identity grouping, be it ethnic, linguistic or otherwise. According to Lijphart,

one of the tests of whether a society is genuinely plural is whether or not its political parties are organised along segmental lines. We can turn this logic around: if we know a society is plural, but cannot identify its segments with complete confidence, we can take our cue from the political parties that form under conditions of free association and competition. (Lijphart, 1991: 72) 
In short, electoral success is an indicator of segmental identity. By this logic, elections on the basis of proportional representation ensure representation for even very small parties. Legitimacy for consociation thus flows from the proportional election of representatives of each segment: 'All of the consociational principles can now be instituted on the basis of self-determination. A grand coalition can be prescribed by requiring that the cabinet be composed of all parties of a specified minimum size in parliament' (Lijphart, 1991: 72). Proportionality in the division of cabinet seats (such as D'Hondt in Northern Ireland), civil service appointments and so on can also be based on this selfdetermined proportionality.

Across his career, Lijphart's views on consociationalism have developed substantially. Differing from his original conceptual structure, he now describes the grand coalition and segmental autonomy as primary characteristics, while proportionality and minority veto are relegated to secondary characteristics (Lijphart, 2002: 39). This evolution of consociational theory is further refined by the work of McGarry and O'Leary who argue that 'what matters is some element of jointness in executive government across all the most significant communities. Consociation does not require every community to be represented in government' (McGarry et al., 2008: 58). This shift in consociational thinkingthat it is the presence of so-called 'significant' communities in power-sharing structures which is most important - has key implications for inclusion. The logic of consociationalism is that it guarantees access to power for certain groups whose exclusion from the state apparatus is deemed unacceptable. The question then becomes who is included or, rather, what groups are acceptable to exclude?

As such, consociational theory envisions and understands an idea of difference, but one in which 'all difference is welcome as long as it is ethnic' (Finlay, 2011: 9). The major failure of this approach is that not all mobilised identities can muster political support by way of election. Indeed, overemphasis on representation via the ballot box will actually serve to further marginalise certain groups beyond the dominant conflictual paradigm as emphasis is placed on electoral support as the sole measure of political legitimacy and engagement. While this may be true of all democracies, the underpinning logic of consociationalism mandates special political arrangements to accommodate groups on the basis of identity. As Byrne and McCulloch argue (2012), there is no logical reason why this logic cannot be expanded to mandate the inclusion of other groups.

\section{Consociational theory and gender}

When considering exclusion beyond the dominant political paradigm in the consociational model, there are two broad groups who fall into this category. The first group generally has comprised what is referred to as 'other' minorities. These may be numerically insignificant indigenous ethnic minorities (such as Vlachs in Macedonia) or immigrant groups (the Chinese community in Northern Ireland). These groups face exclusion from the mainstay of politics partially because of their numerical insignificance and partially the perception of being 'beyond' the politics of the consociational state. The second type of excluded group is one that crosscuts the divisive societal cleavage but which has been, for various cultural and structural reasons, excluded from the formal loci of political engagement in each community. Formal democratic processes in liberal polities understand abstract individual interest and majority rule as the basis of governance. This understanding is clearly reflected in the consociational model of governance; however, the 'abstract interest' is effectively reduced to the single dimension of the conflict. The issue 
then is that groups who have been marginalised due to a history of structural disadvantage (such as women) are rendered invisible.

Iris Marion Young argues that because in liberal democratic polities the rationale of political decisions is justified by the success of the voting procedure, the experiences and interests of the dominant groups in the polity become established as the norm. She describes this phenomenon as

cultural imperialism ... a situation in which the dominant group(s) in society project their own experiences, interests and perspectives as representative of humanity, while those of marginalised groups are silenced or at best forced to be articulate in the languages of the dominant groups. (Young, 2000: 141-142; emphasis added)

In ethno-nationally divided consociational states, we can understand this as the 'hegemony of ethnicity'. In essence, the consociational model deprives non-ethno-specific groups of the chance to participate on an equal footing as those in the political sphere representing ethno-national interests.

The most obvious group that this type of exclusion affects is women, who form half of the polity but face exclusion from the formal politics of the state. While this is true of all societies, we argue here that the particular structure of the ethnically divided consociational state may exacerbate this exclusion, with its emphasis on the ethno-national characteristics of elected officials and quotas. Indeed, many feminist scholars have pointed out the role that peace settlements play in the perpetuation of gender inequality in postconflict societies. It is argued that 'power-sharing political arrangements sacrifice women's claims for equality in the interests of communal unity. In addition [these agreements] provide particular ethno-national groups with the opportunity to further perpetuate their own sexist ideology' (Hayes and McAllister, 2013: 34). This outcome is particularly important for the reality of consociation where the resolution of ethno-national conflict is the chief, if not only, concern.

As in all contemporary democracies, citizens of consociational polities are seen as undifferentiated with regard to their potential to engage politically, either through standing for elections or exercising civil rights as citizens of said state. This assumption does not present a complete picture of how political engagement operates in consociational states. Consociationalism may actually serve as a barrier to effective political representation for marginalised groups that attempt to engage with the state along the lines of socalled 'other' group identity. Societies which have experienced conflict over issues of ethnic differentiation or nationalism have often been described as being characterised by strongly traditional attitudes towards women's roles, which has important implications for the ability of women to influence mainstream political discourse. So-called 'women's issues' are seen as an unnecessary deviation from the 'real' politics of the day. Opportunities for women's political participation are further constrained through their 'primary' identity grouping (where these concerns are often dismissed as a 'distraction') or through independent political action, which is excluded from the mainstream political discourse in divided societies, because the political mobilisation is not of the 'correct' form (Fearon, 1999). This eventuality sees a re-packaging of the types of exclusion that consociationalism seeks to overcome. Unless political mobilisation is framed in the discourse of the primary conflictual identities, it is unlikely to gain momentum in the political mainstay.

In many divided states, the form that women's political participation takes is through small, locally based participatory civil society groups (Hoewer, 2013). This 'situated 
politics of everyday life' (Porter, 1998) generally means that women focus their efforts at political engagement away from the ethno-nationally divided formal public arena of men's involvement:

If feminism's motivation is to integrate women as actors into conventional politics, then women's absence from elected representation is the sole struggle. However, clearly women are engaged in activities outside of male dominated institutional politics and these must be included in an assessment of citizenship. (Porter, 1998: 50; emphasis added)

It is noticeable that this engagement does not improve women's representation in formal political institutions because the two forms of political engagement run along separate tracks: the 'high' politics of providing stable power-sharing governance for the divided society and the 'low' politics of the 'community sector' or civil society.

For those who are associated most strongly with consociationalism in theory and practice, this gender blind spot is acknowledged, but not seen as a problem. The work of John McGarry and Brendan O'Leary is fundamental to contemporary consociational thinking, with global reach in both practical and academic matters (O'Leary et al., 2005; O'Leary, 2005; Taylor, 2009), but most closely linked to the Northern Irish example (McGarry and O'Leary, 1995). Their answer to the critique that consociationalism sections off broader debate on political representation is quite simple: there is no evidence to support public support for greater inclusion by gender or class, so it does not warrant further inquiry:

As for the suggestion that consociational politics promotes a superficial ethno-national politics at the expense of more popular questions of class or gender, we submit that there is no evidence, either from public opinion data or from elections, that the latter questions are more popular. If they were, why do people not vote for parties that put such questions at the top of their agenda? (McGarry and O’Leary, 2009: 82)

In later writing, consociational theory has given greater consideration to gender and how inclusion of women in formal politics might be encouraged, primarily via the use of electoral quotas:

For some, supporting women's political quotas might, indeed, appear to be the antithesis of consociationalism, but in what sense are ethnic identities less 'progressive' than those based on gender? Why are gender quotas apparently less challenging to equality than consociation? Why are some 'essences' better than others? (McCrudden and O'Leary, 2013: 11)

This discussion is, however, brief, and has generated little further thinking on gender from key consociational thinkers. The gendered implications of ethno-national powersharing as outlined here are clear, yet have largely gone unconsidered by mainstream consociational thinking. There is thus a disjoint between our gendered understanding of conflict and consociational governance as a means to 'fix' conflict: without a model for post-conflict structures which addresses the gendered problems of conflict, they cannot be addressed.

Following this overview of academic work, which has highlighted the gendered nature of conflict and the gender blindness of consociational theory, we now turn to the effects of consociationalism on Northern Ireland, one of the most celebrated examples of contemporary consociational governance. Data presented in the following section emanate 
from semi-structured interviews with politicians and feminist activists in the province, undertaken as part of wider research considering gender politics in the region following the Good Friday Agreement (the GFA) of $1998 .^{1}$

\section{Gender and consociational government: the Northern Irish case}

Northern Ireland ended over 30 years of violent conflict via a peace agreement that was strongly consociational in its basic principles. Of the 'new wave' 2 of power-sharing democracies, Northern Ireland 'shines as the brightest star in the consociationalist universe' (Taylor, 2009: 7). With an ethno-national understanding of the province's recent history now the 'most Orthodox explanation of the Northern Ireland conflict' (Edwards, 2007), consociationalism in the province has become a 'model for export' (Wilson, 2010), influencing other peace settlements around the world.

In a liberal consociational set-up such as that envisaged by the GFA, the successful mobilisation of a gendered political identity should have been possible. Indeed, a women's party, the Northern Ireland Women's Coalition (the NIWC), was formed to contest elections to the Forum for Political Dialogue, which contributed to the talks leading to the GFA. The NIWC worked across the sectarian divide, and the two women elected to the Forum talks (Monica McWilliams and Pearl Sagar) were Catholic/ Middle class and Protestant/Working class, respectively. This decision to operate along transversal feminist lines (Yuval-Davis, 1999) went strongly against the grain of the ways in which the conflict had been understood and the manner in which previous attempts at political reconciliation had been attempted (the power-sharing arrangements of the Sunningdale Agreement of 1974 and the reformed and ultimately abortive Assembly of 1982-1986).

Despite the impressive grassroots political and civil society credentials of the women involved, the NIWC delegates often failed to be taken seriously by their colleagues in the Forum. Future First Minister Peter Robinson declared that 'they [the women of the NIWC] haven't been at the forefront of the battle when shots were being fired or when the constitution of Northern Ireland was in peril' (quoted in Fearon, 1999: 14). Then Deputy Leader of the Social Democratic and Labour Party (SDLP), Seamus Mallon, said that the peace negotiations

won't be about setting differences aside, this will be about facing differences that we have in this community, facing them full-frontal and dealing with those differences. What we must realize is that these negotiations which are going to take place are going to be very hard-nosed and they are going to be real. (quoted in Fearon, 1999: 17)

The highly gendered language of both politicians here suggests the disparagement in which male members of other parties held the NIWC. For Mallon, the negotiations are going to be 'real' in the sense that they are going to be work for 'real' men and that the women of the NIWC, despite their cross-community basis, will not be able to cope with the difficult work of 'facing differences'. Likewise, Robinson transplants the male violence of the Troubles onto the party political sphere, with the inference that if women were not present in one, then they should not be present in the other. The attempts of a women's party, consciously not organised around ethno-national concerns, to break into formal peace-making in the province proved problematic. 
This problem was further reflected in the difficulties the NIWC faced following devolution and the advent of the Northern Irish Assembly. McWilliams and Jane Morrice were elected to the first Assembly as NIWC representatives, but lost their seats in 2003. The last remaining NIWC local Councillor failed to be re-elected in 2005. Furthermore, the achievements of the NIWC did not lead to a 'contagion' effect in which other parties felt compelled to encourage women's political representation. Northern Ireland continues to languish behind the other devolved UK institutions in terms of women's representation, with $17 \%$ women representatives in 1998 and only a slight increase to $19.4 \%$ (21 of 108 total members $)^{3}$ in the Assembly of 2011-2016. Any discussion of 'parity' has been monopolised by the ethno-national division, to the extent that there appears little action on the part of most of the parties to do anything to counter the dearth of female representation. ${ }^{4}$

Following the demise of the NIWC, the energy around women's activism returned to the civil society sector where it has a long history (Deiana, 2014; McWilliams, 1995; Porter, 1997). Northern Ireland retains today a vibrant and wide-reaching women's sector. Yet, the ability of this sector to bridge the divide from civil society and to influence and infiltrate formal politics remains weak. Not only does women's descriptive representation remain low (Galligan, 2013), but attempts to organise politically around women's substantive concerns are difficult. Domestic violence legislation remains less developed than the rest of the United Kingdom, and the 1967 Abortion Act has never been extended to the province, rendering abortion effectively illegal in the province (Bloomer and O'Dowd, 2014; Horgan and O'Connor, 2014). A Sexual Orientation Strategy, originally intended to be produced in 2012, is yet to be published or implemented.

The women's sector has made some inroads in attempting to create a discourse at Stormont around women's policy interests. The Northern Ireland Women's European Platform (NIWEP) has established an all-party group at the Assembly on United Nations Security Council Resolution 1325, ${ }^{5}$ which enjoys the membership of seven different political parties. The Family Planning Association (FPA) has also established an All Party Group on Sexual Health. Despite these steps to institutionalise women's substantive interests, there is a sense that these issues are not given great priority by parties. One Member of Legislative Assembly (MLA) who sits on both all-party groups reported that

we only ever have 2 members ever turn up [to the all-party group on sexual health], sometimes 3 ... nobody turns up for them, so you can't go by the membership of it, you go by the attendance of it. ${ }^{6}$

Similarly, in interviews across the political divide, MLAs appeared aware of the need for mechanisms such as UNSCR 1325 and for greater female involvement in formal politics. Although keen to sign onto the liberal principles of a measure such as 1325 in terms of acknowledging the need for greater gender diversity, this enthusiasm has yet to establish itself in the form of tangible policy. Indeed, one women's sector activist described the situation in dire terms: 'you're just always pushing and pushing and pushing and sometime whenever you do get the ear of somebody, you almost feel like getting down on your knees and kissing them but then you think, wise up. This is what they should be doing anyway'. While the establishment of these groups is an important step in having substantive gender issues raised in the formal political arena, these issues appear to be far from high on the political agenda.

Akin to the difficulties faced by the formal women's sector, feminist activists also report difficulties inherent in trying to mobilise around gender politics. Many activists 
linked this problem to the strong ethno-national voting trends: 'it's almost a bi-polar politics, you're either Catholic or you're Protestant, you're either Nationalist or you're Unionist, and your voting blocks come from that' ${ }^{8}$ Similarly, referring to one crosscommunity party, another activist declared that 'it would be great if we had some increase in the MLAs from parties like that who don't follow that traditional sectarian politics'. The strong ethno-national groupings were thus highlighted as a problem for mobilising around women's rights. The dominant ethno-national trends of formal politics create a situation where, in the words of one feminist pro-choice activist, 'women's interests in general, social justice issues in general, have been ignored cos it's more about this notion of achieving parity [between ethno-national communities]'. ${ }^{10}$ Furthermore, the necessity of having bi-ethno-national support forces women's activism to present issues in a particular way, as having cross-community impact, rather than as women's issues. This bias results in a closing down of the arena of political discussion: if issues are not framed or presented in the right way, they struggle to be part of the conversation.

Unsurprisingly, it is women who report the 'highest level of uninterest, disaffection and distrust' (Gormley-Heenan and Devine, 2010: 164) in Northern Irish politics. Similarly, Hayes and McAllister report a significant difference between women and men in the level of trust and support for the consociational power-sharing arrangements in the province, which has grown since devolution (Hayes and McAllister, 2013: 127). In the consociational context of Northern Irish politics, mobilising formal political structures around anything other than the dominant ethno-national tensions appears difficult. In a hierarchy of political identity, in which gender ranks low on the scale, producing movement on women's issues has not been a priority.

\section{Discussion and conclusion}

As Byrne and McCulloch emphasise, 'there is nothing inherent in power-sharing that cannot be made more democratic and inclusive of women' (Byrne and McCulloch, 2012: 566). While we agree with the positive nature of this statement, the example of a liberal consociational set-up as seen in Northern Ireland illustrates the difficulties of this principle. There is little space for 'other' identities in consociational governments, as the difficulties of including women, both descriptively and substantively in the consociational Northern Irish institutions, illustrates. A hierarchy of identity is created, whereby only the most overtly politicised identity, that of ethno-nationalism, has any credence. Women's issues, and representation within the new structures, have continually been sidelined, and consociationalism, in either theory or practice, does not provide answers to this problem.

Feminist theory and academia have long understood that all conflicts are gendered. Yet, consociational theory has no real interaction with gender at all. This blind spot within consociational theory is deeply problematic for consociationalism as an antidote to conflict. Without a complete understanding of the causes and consequences of conflict, power-sharing as a prescription for divided societies is inadequate. With no understanding of gender, consociational mechanisms cannot hope to fully tackle all the injustices created through conflict. As such, the patriarchal underpinnings of conflict are re-inscribed in the formal political institutions that consociationalism creates and the potential to challenge it via newly designed post-conflict institutions is lost.

Furthermore, the emphasis that consociationalism places on formal structures acts to depoliticise the work of women in grassroots and civil society politics. Women's activism in Northern Ireland, and many other post-conflict societies, is mainly present via informal 
bodies, and women's politics largely takes place outside the formal political structure. Although attempts have been made to challenge this exclusion in the past, largely through the short-lived Civic Forum (Bell, 2004), again, they have proved transitory. Women's politics, and women's political issues, remain at a remove from formal party politics and political structures. As such, pressing issues for women, such as abortion law reform, remain woefully under-considered.

This article points to several areas for potential future research. In the contemporary Northern Irish example, policy-making around several key gendered issues (notably same-sex marriage and abortion: Thomson, 2015) has stalled. Veto mechanisms, a key feature of consociational governance, have been used to stop policy change around these issues. The ability to veto legislative change in consociational structures has been little considered (Conley and Dahan, 2013; McEvoy, 2013), but is an important feature of these institutions. Further research is needed to explore whether it is being used to stop progressive movement around gender issues across consociational governments. Mainstream consociational work is also relatively vague on how consociations will 'decay' and 'normal' political practice will resume. Anti-consociational literature (Wilson, 2010) has emphasised what it perceives to be the concretising effect that consociational structures have on ethno-national identities. Research might explore to what extent this has a similar effect on gendered identities. Similarly, in circumstances where consociations do appear to be 'decaying', what effect does this eventuality have on gendered identities and gendered policy issues? Does a breakdown in ethno-national identity encourage more egalitarian gender politics? Furthermore, in terms of reconfiguring institutional arrangements to be more gender-friendly, it should be pointed out that the original GFA contained a provision for the previously mentioned 'Civic Forum'. This body was to act as a counterbalance to the ethno-national governmental structures and to provide an institutionalised mechanism for aggregating voices from grassroots organisations. This innovative aspect of the agreement was quietly shelved following the re-institution of direct rule in 2002 and was not reconstituted when power-sharing resumed in 2007. Subsequent agreements, including the most recent talks on so-called 'legacy issues', have promised a watereddown version of the civic forum. The 'Fresh Start' agreement of December 2015 included a provision for a weak 'Civic Advisory Panel'. Although concrete plans for it to be created have yet to emerge, it could provide a key vehicle in which gendered concerns would be more adequately addressed. Our central argument here-that consociationalism ignores gender - is simple, but opens a door to further research on a little considered aspect of post-conflict structures and the design of new institutions.

This article has demonstrated that because gender is part of the problem (of conflict), models for governance which do not address it as part of the solution (for peace) are problematic. Consociational theory is increasingly employed as a means for stable postconflict governance, and Northern Ireland has been lauded as a key example of its potential. Yet, consociational theory works from a gender-blind understanding of conflict. Whilst liberal consociational set-ups, as witnessed in the short life of the NIWC, illustrate that the political mobilisation of women as women is possible, cross-cutting political identity is difficult to concretise in a divided political set-up. Ethno-nationalism remains the privileged political identity to the detriment of 'other' groups.

Consociationalism, in its lack of a full understanding of the gendered nature of conflict, does not fully address the inequalities and problems that need attention in a postconflict setting and works to reinstate gendered processes of exclusion. The 'Women, Peace and Security' agenda furthered by the United Nations has brought international 
recognition of the differential impact of conflict on women and girls and the exclusion of women from the formal peace-making process. Mainstream consociational theorists and practitioners must now take account of this body of work in developing governance structures for societies emerging from violent conflict in order to further truly equitable societies and sustainable peace.

\section{Funding}

Ronan Kennedy received funding from the Irish Department of Foreign Affairs and Trade Andrew Grene Conflict Resolution Scholarship. Claire Pierson received funding from the Northern Ireland Department of Employment and Learning. Jennifer Thomson received funding from the Economic and Social Research Council under grant number ES/J500124/1.

\section{Notes}

1. The data come from three separate semi-structured interview-based projects, looking at abortion policy, gendered security issues and women's political representation respectively.

2. Taylor (2009: 6) defines the following countries as the 'new wave' of 'strong consociational cases': Bosnia-Herzegovina, Burundi, Macedonia, Afghanistan, Iraq, Kenya and Northern Ireland.

3. 'Women in the Northern Irish Assembly', Northern Ireland Assembly Research and Information Service Research Paper, Michael Potter, 3 September 2013. http:/www.niassembly.gov.uk/Documents/RaISe/ Publications/2013/ofmdfm/10813.pdf (accessed 05 August 2014).

4. Sinn Féin perhaps being the exception here- the party has consciously chosen to put forward women for co-opted seats in the Assembly of 2010-2015. Women are still relatively absent from the upper echelons of the party, however.

5. United Nations Security Council Resolution (UNSCR) 1325 remains unrecognised in the province of Northern Ireland, however, because the British government and the main Unionist parties do not recognise the Troubles as constituting the recognised definition of 'conflict'. As a result, the UK 1325 National Action Plan focuses very much on foreign, as opposed to domestic, policy. The National Action Plan of the Republic of Ireland is similarly internationally focused, although greater effort appears to be being taken on the Irish government's behalf to encourage women's activism in Northern Ireland (Hoewer, 2013).

6. Member of Legislative Assembly (MLA), private interview with the author, Belfast, February 2014.

7. Women's sector employee, private interview with the author, Belfast, July 2014.

8. Political party activist, private interview with the author, Belfast, February 2014

9. Pro-choice activist, private interview with the author, Belfast, February 2014.

10. See Note 9 .

\section{References}

Anderlini SN (2007) Women Building Peace: What They Do, Why It Matters. Boulder, CO: Lynne Rienner Publications.

Ashe F (2007) Gendering ethno-nationalist conflict in Northern Ireland: A comparative analysis of nationalist women's political protests. Ethnic and Racial Studies 30(5): 766-786.

Ashe F (2008) Gender and ethno-nationalist politics. In: Coulter C and Murray M (eds) Northern Ireland after the Troubles: A Society in Transition. Manchester: Manchester University Press, pp. 156-174.

Ashe F (2012) Gendering war and peace: Militarized masculinities in Northern Ireland. Men and Masculinities 15(3): 230-248.

Ashe F and Harland K (2014) Troubling masculinities: Changing patterns of violent masculinities in a society emerging from political conflict. Studies in Conflict \& Terrorism 37(9): 747-762.

Bairner A (1999) Masculinity, violence and the Irish peace process. Capital \& Class 69: 125-144.

Bell C and O'Rourke C (2007) Does feminism need a theory of transitional justice? An introductory essay. International Journal of Transitional Justice 1(1): 23-44.

Bell V (2004) In pursuit of civic participation: The early experiences of the Northern Ireland Civic Forum, 2000-2002. Political Studies 52(3): 565-584.

Bloomer F and O'Dowd K (2014) Restricted access to abortion in the Republic of Ireland and Northern Ireland: Exploring abortion tourism and barriers to legal reform. Culture, Health and Sexuality 16(4): 366-380. 
Byrne S and McCulloch A (2012) Gender, representation and power-sharing in post conflict institutions. International Peacekeeping 19(5): 565-580.

Caprioli M (2005) Primed for violence: The role of gender inequality in predicting internal conflict. International Studies Quarterly 49: 101-178.

Conley RS and Dahan C (2013) Legislative behaviour in the Northern Irish Assembly 2007-2011: Conflict and consensus in a developing consociational democracy. Political Studies 61(Suppl. S1): 179-197.

Connolly L (1999) Feminist politics and the peace process. Capital \& Class 23(3): 145-159.

Day G and Thompson A (2004) Theorizing Nationalism. Basingstoke: Palgrave Macmillan.

Deiana M (2013) Women's citizenship in Northern Ireland after the 1998 agreement. Irish Political Studies 28(3): 399-412.

Edwards A (2007) Interpreting the conflict in Northern Ireland. Ethnopolitics 6(1): 137-144.

Enloe C (1989) Bananas, Beaches and Bases: Making Feminist Sense of International Politics. London: Pandora Press.

Enloe C (2005) What if patriarchy is 'the big picture': An afterword. In: Mazurana D, Raven-Roberts A and Parpart J (eds) Gender, Conflict, and Peacekeeping. Lanham, MD: Rowman \& Littlefield Publishers, pp. 280-284.

Fearon K (1999) Women's Work: The Story of the Northern Ireland Women's Coalition. Belfast: Blackstaff House.

Galligan Y (2013) Gender and Politics in Northern Ireland: The representation gap revisited. Irish Political Studies 28(3): 413-433.

Finlay A (2010) Governing Ethnic Conflict: Consociation, Identity and the Price of Peace. Abingdon: Routledge.

Galtung J (1990) Cultural violence. Journal of Peace Research 27(3): 291-305.

Gellner E (2008) Nations and Nationalism. Ithaca, NY: Cornell University Press.

Gormley-Heenan C and Devine (2010) The 'Us' in Trust: Who Trusts Northern Ireland's Political Institutions and Actors? Government and Opposition 45(2): 143-165.

Hayes B and McAllister I (2013) Gender and consociational power-sharing in Northern Ireland. International Political Science Review 34(2): 123-139.

Hoewer M (2013) Women, violence, and social change in Northern Ireland and Chiapas: Societies between tradition and transition. International Journal of Conflict and Violence 7(2): 216-231.

Horgan G and O'Connor J (2014) Abortion and citizenship rights in a devolved region of the United Kingdom. Social Policy and Society 13(1): 39-49.

Imam A and Yuval-Davis N (2004) Introduction. In: Imam A, Morgan J and Yuval-Davis N (eds) Warning Signs of Fundamentalisms. London: Women Living under Muslim Laws, pp. xi-xviii.

Lijphart A (1977) Democracy in Plural Societies. New Haven, CT: Yale University Press.

Lijphart A (1991) 'Self-Determination Versus Pre-Determination of ethnic Minorities in Power-Sharing Systems'. In: Lijphart A (ed.) 'Thinking About Democracy: Power-Sharing and Majority Rule in Theory and Practice' (2008). New York: Routledge.

Machanda R (2001) 'Guns and Burqa: Women in the Kashmir Conflict'. In: Machanda R (ed.) Women, War and Peace in South Asia: Beyond Victimhood to Agency. New Delhi: SAGE.

McClintock A (1993) Family feuds: Gender, nationalism and the family. Feminist Review 44: 61-80.

McCrudden C and O'Leary B (2013) Courts and Consociations: Human Rights versus Power-Sharing. Oxford: OUP.

McEvoy J (2013) “We forbid!” The mutual veto and power-sharing democracy. In: McEvoy J and O’Leary B (eds) Power Sharing in Deeply Divided Places. Philadelphia, PA: University of Pennsylvania Press, pp. 253-277.

McGarry J (2007) "Iraq: Liberal consociation and conflict management." In Iraq: Preventing Another Generation of Conflict (eds). Ben Roswell, David Malone and Markus Bouillon. Boulder CO: Lynne Rienner Press, pp. 169-188.

McGarry J and O'Leary B (1995) Explaining Northern Ireland: Broken Images. Oxford: Blackwell Publishers.

McGarry J and O'Leary B (2004) The Northern Ireland Conflict: Consociational Engagements. Oxford: Oxford University Press.

McGarry J, O’Leary B, and Simeon R (2008) "Integration or Accommodation: The Enduring Debate in Conflict Regulation.” In: Choudhry S (ed.) Constitutional Design for Divided Societies: Integration or Accommodation? Oxford: Oxford University Press.

McGarry J and O'Leary B (2009) "Power shared after the deaths of thousands". In: Taylor R (ed.) Consociational Theory: McGarry and O'Leary and the Northern Ireland Conflict. Abingdon: Routledge. 
McKay S (1998) The effects of armed conflict on girls and women. Peace and Conflict: Journal of Peace Psychology 4(4): 381-392.

McWilliams M (1995) Struggling for peace and justice: reflections on women's activism in Northern Ireland. Journal of Women's History 6(4).

Meintjes S, Turshen M and Pillay A (eds) (2001) The Aftermath: Women in Post-Conflict Transformation. London: Zed Books.

Melander E (2005) Gender equality and intrastate armed conflict. International Studies Quarterly 49(4): 695714.

Ní Aoláin F (2006) Political violence and gender during times of transition. Columbia Journal of Gender and Law 15(3): 829-849.

O’Leary B (2005) Debating consociational politics: Normative and explanatory arguments. In: Noel S (ed.) From Power Sharing to Democracy: Post-Conflict Institutions in Ethnically Divided Societies. Montreal, QC, Canada: McGill-Queen's University Press, pp. 3-44.

O’Leary B, McGarry J and Salih K (2005) The Future of Kurdistan in Iraq. Philadelphia: University of Pennsylvania Press.

O’Rourke C (2013) Gender Politics in Transitional Justice. Abingdon: Routledge.

Porter E (1997) Diversity and Commonality: Women, Politics, and Northern Ireland. The European Journal of Women's Studies 4(1): 83-100.

Reardon B (1996) Sexism and the War System. New York: Syracuse University Press.

Rebouche R and Fearon K (2005) Overlapping identities: Power sharing and women's rights. In: O'Flynn I and Russell D (eds) Power Sharing: New Challenges for Divided Societies. London: Pluto Press, pp. 155-171.

Rubio-Marín R (2006) What Happened to the Women? Gender and Reparations for Human Rights Violations. New York: Social Science Research Council.

Sales R (1997) Women Divided: Gender, Religion, and Politics in Northern Ireland. Abingdon: Routledge.

Taylor R (2009) Consociational Theory: McGarry and O'Leary and the Northern Ireland Conflict. London: Routledge.

Thomson J (2015) Abortion and same-sex marriage: How are non-sectarian controversial issues discussed in Northern Irish politics? Irish Political Studies. Epub ahead of print 13 November. DOI: $10.1080 / 07907184.2015 .1103226$.

Ward R (2006) Women, Unionism and Loyalism in Northern Ireland: From 'Tea-Makers' to Political Actors. Dublin: Irish Academy Press.

Ward T (2004) State harms. In: Hillyard P, Pantazis C, Tombs S, et al. (eds) Beyond Criminology: Taking Harm Seriously. London: Pluto Press, pp. 84-99.

Wilson R (2010) The Northern Ireland Experience of Conflict and Agreement: A Model for Export? Manchester: Manchester University Press.

Wilson R, Wilford R and Claussen K (2007) Power to the People: Assessing Democracy in Northern Ireland. Dublin: Tasc at New Island.

Young I M (2000) Inclusion and Democracy. Oxford: Oxford University Press.

Yuval-Davis N (1993) Gender and nation. Ethnic and Racial Studies 16(4): 621-632.

Yuval-Davis N (1997) Gender and Nation. London: SAGE.

Zalewski M (2005) Gender ghosts in McGarry and O'Leary and representations of the conflict in Northern Ireland. Political Studies 53(1): 201-221.

Zalewski M and Barry J (2008) Intervening in Northern Ireland: Critically Re-Thinking Representations of the Conflict. London: Routledge. 